\title{
ОРГАНІЗАЦІЯ НАВЧАЛЬНОГО ПРОЦЕСУ ВИКЛАДАННЯ НЕВРОЛОГІЇ СТУДЕНТАМ СТОМАТОЛОГІЧНОГО ФАКУЛЬТЕТУ
}

\author{
Л. Т. Максимчук, О. О. Дорошенко, В. А. Гриб \\ Івано-Франківський національний медичний університет
}

\section{THE ORGANIZATION OF EDUCATIONAL PROCESS OF TEACHING OF NEUROLOGY FOR STUDENTS OF STOMATOLOGICAL DEPARTMENT}

\author{
L. T. Maksymchuk, O. O. Doroshenko, V.A. Hryb \\ Ivano-Frankivsk National Medical University
}

\begin{abstract}
У статті наводиться досвід кафедри неврології Івано-Франківського національного медичного університету 3 підготовки студентів IV курсу стоматологічного факультету за кредитно-модульною системою організації навчального процесу для підвищення якості їх навчання.
\end{abstract}

This article shows the experience of the Neurological Department in Ivano-Frankivsk National Medical University for students of Stomatological Department under credit-modular system of educational process for improving the quality of their learning.

Вступ. Основою підготовки студентів з неврології за кредитно-модульною системою організації навчального процесу є формування у них професійних вмінь та практичних навичок [1]. На кафедрі неврології Івано-Франківського національного медичного університету вивчення дисципліни студентами VI курсу стоматологічного факультету здійснюється шляхом засвоєння модулів-логічно завершених частин навчальної програми [2], що реалізуються відповідними формами організації навчального процесу i закінчуються підсумковим модульним контролем.

Основна частина. Форма організації практичного заняття, яка передбачає оволодіння систематизованими знаннями та професійними вміннями, представлена на прикладі методичної розробки практичного заняття для студентів IV курсу стоматологічного факультету на тему "Прозопалгії. Гангліоніти війчастого, вушного, крилопіднебінного, під'язикового тапідщелепного вузлів".

На початку методичної розробки висвітлюється актуальність теми, коротко вказуються теоретичні основи нозології та практична доцільність вивчення теми студентами стоматологічного факультету. Наступним етапом організації навчального процесу $\epsilon$ формування навчальних цілей заняття та цілей розвитку особистості [3]:

1) ознайомитись $(\alpha=1)$ з поширеністю прозопалгій серед звернень до лікарів-стоматологів та 3 частотою невірного стоматологічного лікування у таких хворих;
$2)$ знати $(\alpha=2)$ функціональну анатомію вегетативної інервації обличчя, топографічну анатомію гангліїв голови, клінічні прояви, діагностику, методи лікування прозопалгій;

$3)$ вміти $(\alpha=3)$ дати топічно-діагностичну оцінку патології вегетативних гангліїв обличчя, правильно провести диференційну діагностику прозопалгій, надати невідкладну допомогу пацієнтам з прозопалгіями, призначити спеціалізоване лікування;

4) сформувати почуття професійної відповідальності за якість життя хворого з гангліонітами, що залежить від проведеної діагностики та вибраної тактики лікування.

Після формування цілей заняття необхідно показати зв'язок теми з предметами, що вивчаються студентами стоматологічного факультету. Для цього формується схема міждисциплінарної інтеграції - вказуються попередньо вивчені забезпечуючі дисципліни та конкретні теми з них для повторення, наступні дисципліни, що забезпечуються вивченням даної теми, та теми з внутрішньопредметної інтеграції, які дозволять студентам скласти чітке уявлення про тему, що вивчається, і ії місце серед неврологічних та стоматологічних нозологій.

Зміст теми подається у вигляді схем та таблиць, які дозволяють чітко структурувати матеріал для полегшення його засвоєння. План та організаційна структура заняття представлені у таблиці 1.

() Л. Т. Максимчук, О. О. Дорошенко, В. А. Гриб 
Таблиця 1. План та організаційна структура заняття

\begin{tabular}{|c|c|c|c|c|c|}
\hline $\begin{array}{c}\text { Етапи заняття, їх } \\
\text { функції, зміст }\end{array}$ & $\begin{array}{c}\text { Навчальні } \\
\text { цілі в рівнях } \\
\text { засвоєння } \\
\end{array}$ & $\begin{array}{c}\text { Методи контролю і } \\
\text { навчання }\end{array}$ & \multicolumn{2}{|c|}{$\begin{array}{c}\text { Матеріали методичного } \\
\text { забезпечення: контролю, наочності, } \\
\text { інструктивні, обладнання }\end{array}$} & Час \\
\hline \multicolumn{6}{|c|}{ Підготовчий етап } \\
\hline $\begin{array}{c}\text { Організація заняття. } \\
\text { Постановка } \\
\text { навчальної мети та } \\
\text { мотивації. } \\
\text { Контроль вхідного } \\
\text { рівня знань }\end{array}$ & II & $\begin{array}{c}\text { Індивідуальне усне } \\
\text { опитування, тестовий } \\
\text { контроль II рівня, } \\
\text { типові задачі II рівня, } \\
\text { письмова теоретична } \\
\text { робота }\end{array}$ & $\begin{array}{c}\text { Тести II рівня, } \\
\text { типові задачі II } \\
\text { рівня }\end{array}$ & $\begin{array}{c}\text { Схеми } \\
\text { гангліїв } \\
\text { голови, } \\
\text { схеми } \\
\text { заняття }\end{array}$ & $15 \mathrm{xB}$ \\
\hline \multicolumn{6}{|c|}{ Основний етап } \\
\hline $\begin{array}{c}\text { Формування } \\
\text { практичних навичок } \\
\text { i професійних вмінь }\end{array}$ & III & $\begin{array}{c}\text { Практичний тренінг, } \\
\text { професійний тренінг } 3 \\
\text { вирішенням } \\
\text { нетипових клінічних } \\
\text { задач III рівня }\end{array}$ & $\begin{array}{c}\text { Професійний } \\
\text { алгоритм } \\
\text { формування } \\
\text { практичних навичок } \\
\text { і професійних вмінь, } \\
\text { нетипові клінічні } \\
\text { задачі III рівня } \\
\end{array}$ & $\begin{array}{l}\text { Хворі, історії } \\
\text { хвороб }\end{array}$ & $65 \mathrm{xB}$ \\
\hline \multicolumn{6}{|c|}{ Підсумковий етап } \\
\hline $\begin{array}{c}\text { Контроль та корекція } \\
\text { рівня професійних } \\
\text { вмінь та практичних } \\
\text { навичок } \\
\text { Підведення } \\
\text { підсумків заняття } \\
\text { (оцінювання). } \\
\text { Домашнє завдання }\end{array}$ & III & $\begin{array}{c}\text { Контроль навичок, } \\
\text { оцінка результатів } \\
\text { клінічної роботи, } \\
\text { нетипові задачі III } \\
\text { рівня, тестовий } \\
\text { контроль III рівня }\end{array}$ & $\begin{array}{l}\text { Нетипові клінічні } \\
\text { задачі III рівня, } \\
\text { тести III рівня }\end{array}$ & Муляжі & $10 \mathrm{xB}$ \\
\hline
\end{tabular}

Для забезпечення взаємодії студентів та викладача на занятті й контролю за процесом отримання знань та професійних вмінь у методичній рекомендації подаються матеріали методичного забезпечення, що включають в себе набір методик контролю на всіх етапах заняття [4]:

1) матеріали контролю на підготовчому етапі: питання для усного опитування (функціональна та топографічна анатомія гангліїв голови, клініка, діагностика та лікування прозопалгій), тестові завдання II рівня (тести з кількома відповідями, тести на визначення відповідності, тести на послідовність), типові задачі II рівня з визначенням клінічного діагнозу;

2) матеріали методичного забезпечення основного етапу заняття подаються у вигляді професійного алгоритму формування навичок та вмінь обстеження хворих з гангліонітами. В алгоритмі вказується послідовність запитань та дій при зборі анамнезу i огляді хворого, даються основні рекомендації щодо формування топічного та клінічного діагнозу, виявлення диференційних рис, які дають можливість за- підозрити або виключити у хворого стоматологічний чи неврологічний діагноз, складання схеми обстеження та лікування;

3) матеріали контролю заключного етапу: тестові завдання III рівня (тести на заповнення структурнологічних схем), нетипові задачі III рівня (задачі, які передбачають проблему диференційної діагностики, задачі з недостатніми даними, задачі на пошуки помилок);

4) матеріали методичного забезпечення самопідготовки студента: орієнтовна карта роботи з літературою, в якій викладені основні теми заняття та вказівки щодо складання схем і планів, які дозволять структурувати отриману інформацію іполегшити засвоєння теоретичних знань.

Завершальним елементом методичної розробки $\epsilon$ список літератури (навчальної та наукової), що нею можуть скористатися студенти при підготовці до заняття.

Висновок. Чітка організація навчального процесу при викладанні неврології студентам стоматологічного факультету полегшує здобування професій- 
них навичок та вмінь і дає можливість контролювати та оперативно коригувати процес навчання. Теоретичне обгрунтування, практичне спрямування та обов' язковий контроль набутих знань при вивченні

\section{Література}

1. Волосовець О. П. Питання якості освіти в контексті впровадження засад Болонської декларації у вищій медичній школі / О. П. Волосовець // Медична освіта. - 2005. - № 2.C. $12-16$.

2. Вища освіта України і Болонський процес : навчальний посібник / [ за ред. В. Г. Кременя ]. - Тернопіль : Навчальна книга-Богдан, 2004. - 384 с. курсу неврології дозволяють оволодіти знаннями, які сприятимуть ефективній диференційній діагностиці та вибору вірної тактики лікування у хворих з проявами нейростоматологічних синдромів.

3. Мілерян В. Є. Медичні основи підготовки і проведення навчальних занять в медичних вузах (методичний посібник) / В. С. Мілерян. - Київ : Хрещатик, 2006. - 84 с.

4. Артемчик Л. М. Принципи створення тестових завдань / Л. М. Артемчик // Медична освіта. - 2003. - № 2. - С. 67-68. 